Abstracta Iranica Abstracta Iranica

Revue bibliographique pour le domaine irano-aryen

Volume 29 | 2008

Comptes rendus des publications de 2006

\title{
Farhang-e vāžesāzī dar zabān-e färsī (Comprehensive Guide to Farsi Word Composition). 8 volumes, Tehrān, Qașīde-sarā, 1385/2006.
}

\section{Pollet Samvelian}

\section{(2) OpenEdition}

10 Journals

\section{Édition électronique}

URL : http://journals.openedition.org/abstractairanica/24462

DOI : 10.4000/abstractairanica.24462

ISSN : 1961-960X

Éditeur :

CNRS (UMR 7528 Mondes iraniens et indiens), Éditions de l'IFRI

\section{Édition imprimée}

Date de publication : 15 mai 2008

ISSN : 0240-8910

\section{Référence électronique}

Pollet Samvelian, « Farhang-e vāžesāzī dar zabān-e fārsī (Comprehensive Guide to Farsi Word Composition). 8 volumes, Tehrān, Qașīde-sarā, 1385/2006. », Abstracta Iranica [En ligne], Volume 29 | 2008, document 28, mis en ligne le 15 septembre 2008, consulté le 26 septembre 2020. URL : http:// journals.openedition.org/abstractairanica/24462; DOI : https://doi.org/10.4000/abstractairanica. 24462

Ce document a été généré automatiquement le 26 septembre 2020.

Tous droits réservés 


\title{
Farhang-e vāžesāzì dar zabān-e fārsī (Comprehensive Guide to Farsi Word Composition). 8 volumes, Tehrān, Qașīde-sarā, 1385/2006.
}

\author{
Pollet Samvelian
}

1 L'objectif de cette vaste entreprise (huit volumes et plus de 1400 pages en totalité) est de décrire de façon exhaustive les différentes possibilités de construction lexicale en persan et d'illustrer chaque construction d'une liste plus moins fournie d'unités lexicales.

2 Le 1er volume présente les mots simples regroupés en huit classes de parties du discours (noms, adjectifs, adverbes, pronoms, mots outils, numéraux et verbes), et une description des procédés de dérivation par affixes et de composition. Il comporte également une liste de « verbes composés » ou plus précisément de phrasèmes verbaux. Les volumes 2 et 3 sont consacrés à la composition au sens large : phrasèmes verbaux, adjectifs et noms composés. Le $4^{\mathrm{e}}$ volume décrit la formation des mots techniques et scientifiques. Les volumes 5 et 6 traitent de la dérivation préfixale et suffixale. Enfin, les deux derniers volumes sont consacrés à la formation du vocabulaire scientifique, culturel et technique. Sont abordés non seulement des constructions persanes à proprement parler, mais également des dérivés et composés avec des éléments d'emprunts au latin ou grec. Bien qu'il s'agisse d'un travail extrêmement utile, on regrettera l'absence d'un chapitre introductif expliquant clairement les principes de classification adoptés par l'auteur et qui ont présidé à l'établissement de différents groupes de lexies complexes. Ceci d'autant plus qu'en l'absence d'index il n'est pas toujours aisé de se référer au volume approprié sans avoir parcouru au préalable la table des matières voire des chapitres de plusieurs volumes. 
INDEX

Thèmes : 2.2. Langues vivantes et dialectes

\section{AUTEURS}

POLLET SAMVELIAN

Sorbonne Nouvelle-Paris III - Mondes iranien et indien - Paris 